\title{
Effective utilisation of National Rural Health Mission flexi-fund in Jharkhand: facilitators, barriers and options
}

\author{
Suranjeen Prasad ${ }^{1}$, Sapna Surendran², Tapan Chakraborty², Supriya Minz ${ }^{2}$, Avinash Ansingkar ${ }^{3}$, Arti Bhanot ${ }^{3}$, \\ Rajan Kumar $^{4}$
}

From First National Conference on Bringing Evidence into Public Health Policy (EPHP 2010)

Bangalore, India. 10-11 December 2010

\section{Introduction}

The National Rural Health Mission (NRHM) provides flexi-fund (a financing mechanism enabling pooling of money from fixed budget heads to be flexibly used as per local needs) to states and districts for paying for urgent but discreet expenses pertaining to maintenance of health infrastructure and provision of services at district, block and village level.

Decisions on use of such fund is to be made locally through various bodies/committees at district, block and village levels such as District Health Societies (DHS), Rogi Kalyan Samitis (RKS), Panchayati Raj Institutions (PRIs), Village Health and Sanitation Committees (VHSC) and village level health and Integrated Child Development Services (ICDS). Various policy documents and guidelines are available on use of flexi-fund.

Primarily, this fund is meant to ensure that health institutions at all the levels for healthcare services have readily available fund to overcome any bottlenecks that arise in the delivery of public health services. Amount of the flexi-find at various levels of healthcare services has been fixed (Table 1).

As per the financial monitoring reports available from the state government, the utilisation of AMGs at primary health centres and community health centres level has remained around 50\% in years 2008-09 and 2009-10. Utilisation of untied fund at health sub-centre level has been about $30 \%$ during the same years. Utilisation of untied fund at the village level by VHSCs has remained low.

We conducted this study to identify factors that impede or facilitate utilisation of flexi-fund at district and sub-district level. We aimed to use the findings of this study to developed revised operational guidelines on use of flexi-fund for consideration by state government.

\section{Methods}

We reviewed relevant literature and used lessons from our work (using problem-solving approach) with health

Table 1 Allocation of flexi-fund per year at various levels of healthcare services

\begin{tabular}{cccc}
\hline Level of healthcare services & \multicolumn{3}{c}{ Flexi-fund INR (USD) } \\
\cline { 2 - 4 } & Untied Fund & Annual maintenance Grants (AMG) & RKS \\
\hline District & NA & NA & $5,00,000(10736.5)$ \\
Block (community health centres) & $50,000(1073.7)$ & $1,00,000(2147.3)$ & $1,00,000(2147.3)$ \\
Block (primary health centres) & $25,000(536.8)$ & $50,000(1073.7)$ & $1,00,000(2147.3)$ \\
Village (health sub-centres) & $10,000(214.7)$ & $10,000(214.7)$ & NA \\
Village (VHSC) & $10,000(214.7)$ & NA & NA \\
\hline
\end{tabular}

* Correspondence: sapna.cini@gmail.com

${ }^{2}$ Child In Need Institute, Ranchi, Jharkhand, India

Full list of author information is available at the end of the article

(c) 2012 Prasad et al; licensee BioMed Central Ltd. This is an open access article distributed under the terms of the Creative Commons 
Table 2 Barriers related to underutilisation of specific type of flexi-fund

\begin{tabular}{|c|c|c|}
\hline Level & Type of fund & Barriers to utilisation of flexi-fund \\
\hline District and block & RKS & $\begin{array}{l}\text { Formation and registration of district level societies } \\
\text { Lack of clarity for technical and management Units }\end{array}$ \\
\hline Block & AMG & Lack of clarity on accountability and role of managers in fund utilisation \\
\hline Village (health sub-center) & AMG, Unitied fund & $\begin{array}{l}\text { Lack of operational guideline } \\
\text { Frontline health workers are new to fund management } \\
\text { Guidelines for utilisation of fund prescribe specific items (against the principle of 'untied' fund) }\end{array}$ \\
\hline Village (VHSC) & Untied fund & $\begin{array}{l}\text { Delayed formation and registration of VHSCS } \\
\text { Absence of PRI in the state } \\
\text { Frontline health workers and VHSC members are new to fund management }\end{array}$ \\
\hline
\end{tabular}

services to understand issues affecting underutilisation of flexi-fund in Jharkhand.

\section{Results}

We observed that late release of fund and lack of clarity on decision-making processes as well as operational guidelines in regard to utilisation of flexi-fund were barriers to effective utilisation of flexi-fund. Other issues included poorly defined auditing as well as supervision/ monitoring systems and lack of orientation to fund managers.

\section{Discussion}

Our findings suggest that existing guidelines for use of flexi-fund need revision in order to make them comprehensible and useful for fund managers and users. Any revisions in programme guidelines/implementation should be followed up to assess the appropriateness and effectiveness of revisions.

There is need to build capacity of fund managers especially as many of the staff appointed as fund managers are dealing with fund management first time. There is need to strengthen monitoring and evaluation systems. Despite political and socio-economic variations across the country, there is tremendous scope for adapting existing best practices from other states.

\section{Author details}

${ }^{1}$ Public Health Resource Network, Jharkhand, India. ${ }^{2}$ Child In Need Institute, Ranchi, Jharkhand, India. ${ }^{3} \mathrm{MCH}-S T A R$ (USAID), India. ${ }^{4}$ State Programme Management Unit, Jharkhand, India.

Published: 16 January 2012

doi:10.1186/1753-6561-6-S1-P7

Cite this article as: Prasad et al:: Effective utilisation of National Rural Health Mission flexi-fund in Jharkhand: facilitators, barriers and options. BMC Proceedings 2012 6(Suppl 1):P7.
Submit your next manuscript to BioMed Central and take full advantage of:

- Convenient online submission

- Thorough peer review

- No space constraints or color figure charges

- Immediate publication on acceptance

- Inclusion in PubMed, CAS, Scopus and Google Scholar

- Research which is freely available for redistribution

Submit your manuscript at www.biomedcentral.com/submit
C BioMed Central 